\title{
Successes and Challenges in Sustainable Development Goals Localisation for Host Communities around Kruger National Park
}

\author{
Mashudu Andra Mabibibi, Kaitano Dube *(1) and Konanani Thwala
}

check for updates

Citation: Mabibibi, M.A.; Dube, K.; Thwala, K. Successes and Challenges in Sustainable Development Goals Localisation for Host Communities around Kruger National Park. Sustainability 2021, 13, 5341. https:// doi.org/10.3390/su13105341

Academic Editor: Brian Garrod

Received: 15 April 2021

Accepted: 3 May 2021

Published: 11 May 2021

Publisher's Note: MDPI stays neutral with regard to jurisdictional claims in published maps and institutional affiliations.

Copyright: (c) 2021 by the authors. Licensee MDPI, Basel, Switzerland. This article is an open access article distributed under the terms and conditions of the Creative Commons Attribution (CC BY) license (https:// creativecommons.org/licenses/by/ $4.0 /)$.
Department of Tourism and Integrated Communication, Vaal University of Technology, Vanderbijlpark 1900, South Africa; 216139945@edu.vut.ac.za (M.A.M.); konananim@vut.ac.za (K.T.)

* Correspondence: kaitanod@vut.ac.za; Tel.: +27-7-1009-6290

\begin{abstract}
Tourism has often been blamed for its unsustainable ways for a number of years now. Consequently, there have been efforts to ensure that tourism contributes to the host communities to address some of the sustainability challenges through responsible and sustainable tourism initiatives in the recent past. With less than nine years to go before the lapse of the Sustainable Development Goals (SDGs), there is a need to take stock of how tourism enterprises such as national parks are contributing to the SDGs. This study examines how Kruger National Parks (KNP) is assisting the host communities in meeting the SDG goals and targets. The study made use of 30 in-depth key informant interviews, field observations and critical document analysis. The study found that regardless of the challenges it faces as an organization in partnering with host communities for developmental purposes, Kruger National Park has assisted communities to meet at least 15 out of the 17 SDGs. These span from social to economic, environmental and cultural SDGs. Since KNP's projects address host community needs, several challenges need to be dealt with to ensure the sustainability of these projects post COVID-19 pandemic, which has undermined many nature tourism establishments worldwide. Besides the pandemic, there is a need to manage community expectations with regard to how far it can address some of the challenges faced by communities.
\end{abstract}

Keywords: Sustainable Development Goals; nature tourism; national parks; host community; responsible tourism; South Africa; sustainable tourism

\section{Introduction}

Hostility and acrimony often punctuate the relationship between protected areas and the host community in many tourism destinations, such as national parks. Issues such as human-wildlife conflict are quite topical in communities surrounding national parks across the world. According to Stoldt, Göttert, Mann and Zeller, [1] such conflicts often arise due to population pressures which result in human encroaching into wildlife space. In some instances, an increase in animal population and demand for resources results in animals encroaching on human beings' spaces. When animals encroach on human space, this often results in the destruction of property, crops, injuries and sometimes loss of human life, much to the annoyance of host communities, triggering conflict [2-4]. This is also confirmed by Madden [5] (p. 248), who notes that human-wildlife conflicts (HWCs) occur "when the needs and behaviour of wildlife impact negatively on the goals of humans or when the goals of humans negatively impact the needs of wildlife. These conflicts may come when wildlife damage crops, injure or kill domestic animals and threaten or kill people."

Protected areas, therefore, are an inconvenience to their host and neighbouring communities. This is in sharp contrast to the glorious picture of a tourism sector that is central to development and the important global economic driver that the tourism industry is known to be [6-8]. When such conflicts occur, critical questions are often raised by so- 
ciety regarding the costs and benefits of nature tourism to the host community and its sustainability. Such questions are even more critical now, as poverty in rural communities in Africa is due to the adverse impacts of climate change, of which tourism is both a victim and a perpetrator [9]. In many rural areas across the world, tourism is often seen as a vehicle for tackling poverty, inequality and employment challenges [10]. These are some of the critical issues which the Agenda 2030 seeks to address.

With that in mind, there has been a serious push across the world to ensure that tourism embraces some semblance of sustainability by adopting the ethos encompassed by the Agenda 2030 on Sustainable Development Goals (SDGs) [11]. According to Liburd, Duedahl and Heape [12], sustainability within the tourism realm can only be achieved through collaboration, partnerships and cooperative efforts, as envisaged under SDG17partnership for the goals. As much as several case studies have been showcased on tourism and SDGs nexus profiling, private-sector initiatives, little is known about how national parks worldwide have responded to the SDG agenda. Such a scenario is problematic, as its results impede an understanding of how national parks can meaningfully contribute to rural development. This can lead to tension and contestations between protected areas and their host communities.

Chidakel, Eb and Child [13] argued that there is generally a lack of knowledge on the socio-economic benefits of protected areas to host communities in developing countries, as these are often poorly documented. Similar concerns are equally raised by Siakwah, Musavengane and Leonard [14], who argue that where sustainable tourism governance frameworks have been used, they often failed to meet expectations and have been found to be unjust, as power dynamics have often been unfairly balanced against the local populace. Understanding how the SDG adoption by the sector has gone in alleviating such challenges is crucial in that regard as the quest for an equitable, sustainable tourism model is sought.

With SDGs having been adopted in the past five years with less than nine years to their lapsing, there is a need to take stock of how tourism has fared in partnering host communities for Sustainable Development Goals as envisaged under SDG 17. Such studies are crucial in as much as they highlight the successes and challenges experienced thus far. They also offer an opportunity for technocrats, policymakers and academics to identify gaps and areas of improvement. This study aims to examine the success and challenges faced by Kruger National Park in partnering host communities to meet their Sustainable Development Goals and targets. The research seeks to answer the following research questions: (i) How can national parks assist host communities in achieving their Sustainable Development Goals and targets? (ii) What are the key challenges faced by national parks as they assist host communities in achieving their SDG goals and targets? The study is crucial in as much as it contributes to the debate on tourism and Sustainable Development Goals locally and globally.

\section{Literature Review}

According to Sharpley [15], sustainable tourism is a must, although it is a dream that is often challenging to achieve, if not altogether unachievable. Although sustainable tourism as a concept is arguably unachievable, Sharpley [15] (p. 1933) encouraged stakeholders "to seek or encourage more sustainable forms of tourism-in contemporary parlance, to act 'responsibly,' this should be done 'without hiding behind the politically acceptable yet ... inappropriate banner of sustainable development." In support, Liburd et al. [12] argued that cooperation within the community and tourism entities could identify mutually agreed goals on projects aimed at addressing the socio-economic aspirations of host communities. That kind of approach ensures equity and triggers sustainable development in host communities. Nowhere is this approach most needed than in areas where potential conflict is imminent, such as at the borderlines of national parks. This approach can assist in easing tension, paving the way for the peaceful coexistence of rural communities and national parks. The peaceful co-existence in protected areas, particularly in rural communities, is critical, as the two are often dependent upon each other [16]. National parks are a 
crucial source of rural development, as they provide numerous economic opportunities and employment, while a peaceful co-existence is crucial for tourism development. However, ensuring community participation in tourism community development projects in line with a sustainable tourism ethos entails numerous challenges [17].

Human-wildlife conflict is a persistent reality in protected areas such as national parks and peace parks across Africa and other parts of the world-see, for example, Long et al. [3]; in Kenya, Doubleday [18], in India; Braczkowski et al. [19], in Uganda; and Fang et al. [20], in China. The conflict between host communities is not limited to the countries mentioned above, as South Africa grapples with the same challenges, with host communities demanding more benefits from protected areas within their vicinities and tourism development with equity. Swemmer, Mmethi and Twine [21] argued that in Kruger National Park, the benefits derived from tourism in the park were not being enjoyed by those who bear the costs of the establishment. As such, communities around the Kruger National Park have been calling for greater inclusion in the park's operations so as to derive more benefits from the park's tourism-related operations [22]. According to Leonard and Thomas [23], there is a need for Kruger National Park (KNP) to ensure that local communities receive benefits from the park by creating employment and ensuring cultural and shareholding dimensions in some of its operations.

On the other hand, some believe that there are already some benefits accruing to the host communities surrounding KNP. It must be noted that Kruger National Park, as a conservation authority, can only do so much, something that is often forgotten by host communities that are battling poverty, inequality and high levels of unemployment. According to Lenao, Moswete and Stone [24], the debate on how far tourism enterprises can contribute to community development is a raging issue that is ongoing. Pope, Wessels, Douglas, Hughes and Morrison-Saunders [25] noted that with the adoption and ratification of a responsible tourism ethos, tourism could play a more critical role in bettering lives. Responsible tourism is a form of tourism that is concerned with the impacts of tourism on people, ecology and communities and focuses on ameliorating the negatives of tourism by ensuring that benefits accrue to the host communities, along with an improvement on the standard of living for tourism employees. One such approach to ensuring sustainable and responsible tourism is the usage of Environmental Impact Assessment (EIA) in all development projects. Strickland-Munro, Moore, and Freitag-Ronaldson [26] argued that there were some economic benefits from the park, but that these were not being adequately reported upon by SANParks and Kruger National Park due to the absence of a reporting framework.

With the world having adopted the Sustainable Development Goals (SDGs) in 2015, the tourism representative board at the United Nations declared the year 2017 as a Year of Sustainable Tourism [27], whereupon nation states and the tourism business were expected to implement the SDG initiatives locally. In that regard, the tourism industry was expected to align business operations to these globally inclusive goals. Since then, several authors have written and suggested that tourism can be used to achieve global goals $[28,29]$. The adoption of SDGs is anticipated to assist various tourism entities in responding to responsible tourism demands [30]. Achieving responsible tourism has been a contentious issue for the tourism sector, given the broad aspects that the tourism industry had to respond to-among others, balancing tourist needs and wants with social and environmental demands [31].

The ethos of SDGs is centred on leaving no one behind. The effort to ensure equity in terms of benefits from the tourism industry has been an issue of concern, with communities often feeling left out of the development agenda by tourism enterprises even when appropriate models of sustainable tourism development are applied [32,33]. Given the challenges that have been experienced in ensuring that host communities derive some benefits from tourism development, there is a constant need for various tourism enterprises to ensure that they take stock of their efforts to ensure that such efforts are responsive to stakeholder demands, to ensure sustainability. Practising responsible and sustainable 
tourism has practical benefits for the tourism business, as it ensures a harmony with host communities and nature which forms the foundation of an excellent tourism experience for tourists [34].

Previous studies have demonstrated the benefits of SDG localization in the tourism industry within the private sector in Southern Africa. Of note has been the contribution of wildlife companies in assisting the host communities through the provision of water and sanitation and supporting the educational empowerment initiatives of host communities [8]. According to Movono and Hughes [35], SDG localization within the tourism sector in the global South requires a partnership that is predicated on understanding the tourism establishments and host communities, and the process is often fraught with challenges. Therefore, there is always a need to take stock of what works and what does not work in SDG localization in that vein. This study, therefore, is part of that stock-taking exercise and is anticipated to contribute to a sustainable and responsible tourism agenda. The global North narrative has often dominated this debate at the expense of the global South. Even though the SDGs are global, most SDGs are indeed focused on addressing the challenges faced by the global South, such as increasing poverty, hunger and inequality. The conclusions drawn from this research are critical in informing policy and practice regarding SDGs in national parks.

This study emanates from a Master's degree project that seeks to use the Sustainable Development Goals approach to examine the contribution of South African National Parks to neighbouring host communities. The understanding of sustainable tourism in protected areas in the SDG context has been utilised in other studies in the region by Dube and Nhamo [8] and Stone et al. [36].

\section{Materials and Methods}

The study focused on the Southern parts of Kruger National Park communities in the province of Mpumalanga. Kruger National Park is one of the most prominent national parks in Southern Africa and the continent. Prior to COVID-19, Kruger National Park was one of the most visited National Parks in South Africa, second only to Table Mountain National Park [37]. The park has a long history that dates to 1898. The park started as a government game reserve between Sabie and Crocodile River, and was later promulgated as a national park in 1926. The park's development was built extensively at the expense of tribal communities, that were driven off their land when the park evolved over the years. Stretching over 1,918,140 ha, the park lies over two provinces of Mpumalanga and Limpopo, over the Ehlanzeni, Mopani and Vhembe districts. The park is part of the Great Limpopo Transfrontier Park, sharing its borders with Gonarezhou National Park, in Zimbabwe, and Limpopo National Park, in Mozambique. This study was largely centred on areas in Mpumalanga Province, around the Ehlanzeni District Municipality, which comprise three municipalities: Bushbuckridge, Mbombela and Nkomazi.

A mixed-method design was adopted for this study which utilized a case study research approach. The case study research was preferred because it allowed for an in-depth and closer look at the study area. Data were gathered through key informant interviews that involved all key stakeholders from the surrounding communities and South African National Parks (SANParks) working in Kruger National Park (KNP). A snowball approach was used to identify key informants through initial advice from Kruger National Park's gatekeepers. In-depth interviews were conducted with the head of community development projects, support employees and other SANParks employees who are often involved in projects that interact with communities, most of whom are project leaders at the managerial level. All in all, $20 \mathrm{KNP}$ employees participated in these in-depth interviews. The interviews, conducted under strict COVID-19 protocols in March 2021, took an average of 45 minutes to an hour. The interviews were conducted at Kruger National Park's Skukuza offices. A guided interview was adopted, which made use of prepared questions that focused on various projects being conducted by the national park in host communities. Questions centred on the nature of the projects, the costs involved, 
the number of beneficiaries of such projects and the duration of such projects. Questions with regard to the challenges and opportunities of such projects were also posed in these indepth interviews. During the interviews, audio recordings were made with the participants' permission, notes were taken and follow-up questions were made where applicable to understand the issues under examination.

The researchers also conducted in-depth interviews with community members, including educators from surrounding schools, a local traditional chief, executive management of companies with concessions in the national park and other people with projects that benefited from the park. The interviews with community members were undertaken in the host communities and followed the manner described above. In total, about 10 external stakeholders were consulted in the process for the triangulation process.

The interview questions centred on various interventions and projects that SANParks were carrying out in the surrounding communities. The in-depth interviews focused on the levels, quantity, type of projects and duration of the various community projects. Challenges and opportunities in community projects were also interrogated to understand SANParks' and the host community's relationship dynamics. Field observation exercises were also undertaken to verify and authenticate the submissions made by SANParks and the community with regard to the community projects.

Direct observation is a well-documented, acceptable and one of the oldest scientific methods available to researchers [38]. During field observations, field notes were made of the observed variables and photographic images were taken as part of field notes and evidence, as dictated by Mulhall [39]. Moreover, the study gathered the views of 70 youths who work in the park on a part-time basis under the public works programme, and who reside in the nearby communities. A snowball sampling technique was used to identify the respondents. This was done using an online questionnaire that comprised close- and open-ended questions. The figure comprises about $75 \%$ of the employees working in the Southern part of the national park. The questionnaire centred on questions covered in the interviews as part of the triangulation process to ensure internal and external validity [40]. Besides, archival records of community projects were investigated.

The data analysis for the interview was transcribed and organised into 17 thematic areas developed and guided by Sustainable Development Goals, in line with the 17 SDGs. The thematic analysis allowed for the deduction of meaning and the description of the phenomenon under study [41]. Data from the online platform was analysed using QuestionProText Analysis, an online-based tool with multiple analysis functions. The preliminary visual screening was done on textual response, and the tag function was applied to determine the frequency of various thematic responses. Content analysis was used to analyse archival data. The research was done in line with the approved ethics requirement of the Vaal University of Technology.

\section{Results and Discussion}

The study found that, given the financial spin-offs from the national park's tourism and other related tourism business activities, the Kruger National Park, in line with the dictates of responsible and sustainable tourism, is helping communities to meet part of their Sustainable Development Goals and targets in several ways. Such efforts respond to SDG17-partnership for goals that call for businesses to partner societies to meet their developmental aspirations. The study found that KNP, run by SANParks, is particularly visible on SDGs related to education, employment creation and economic development. KNP chose to embed SDGs related to its co-mandate of conservation and SDGs aligned to SDG15-life on land into many of its projects to ensure maximum returns on investment. Using funds from tourism levy and other tourism receipts, SANParks, through KNP, has made significant efforts in assisting host communities to improve their standard of living, with a major focus on those who reside in the park's $20 \mathrm{~km}$ radius. The following sections seek to report on various main SDGs that SANParks projects respond to in order of their visibility and prominence. 


\subsection{South African National Parks and SDGs for Social and Economic Development}

While the tourism industry is ordinarily understood to have the capacity to address all the SDGs, as discussed earlier, the UN General Assembly assigned three specific goals to the tourism industry, namely SDG 8-decent work and economic growth, SDG 12-responsible consumption and production and SDG14-life below water [42]. Accordingly, with regard to SDG 8, it was noted that Kruger National Park, which is largely rural and peri-urban, creates direct and indirect employment opportunities for the host community. It emerged from interviews that as part of its responsible tourism agenda, the park prioritises people's employment from the host community in its recruitment drive. Authorities indicated that about $90 \%$ of Kruger National Park's general employees come from the local community. KNP managers indicated that whenever there is an employment opportunity, priority is given to local candidates, with job advertisements circulated through community forums that comprise members within a $20 \mathrm{~km}$ radius from the park's boundary. This allows local people to make applications and be considered for whatever job opportunities could be available. The job opportunities that come from South African National Parks refer mostly to permanent jobs that pay market-related salaries and are therefore considered sustainable jobs, as they contribute to poverty eradication, as encompassed in SDG1-no poverty.

Other job streams come from entities that have concessions in and around the park, which assist in providing additional employment opportunities to local community members. Some of these concessions include various establishments, such as the opening of convenient shops, accommodation, safaris and the promotion of private game reserves around the park, amongst other such establishments. One of the conditions set up by Kruger National Park in entering concessions with various establishments is that the businesses which get concessions in the park follow the ethos set up by SANParks with regard to host community empowerment. This means the establishment must contribute to local employment by recruiting from the local community as far as possible. As such, like other such tourism establishments, the national park is having a positive ripple impact on KNP neighbouring communities.

The Kruger National Park has also been assisting the establishment of community projects and ventures as a supplementary measure to its efforts of creating employment. In the Southern part of the park, the study focused on two flagship and successful community projects established at the Numbi Gate, namely the Nkambeni Safari Camp and Mdluli Safari Lodge flagship community projects. The two establishments offer a luxury safari experience. It emerged that in some of the projects, the community owns a $50 \%$ stake. From these enterprises, communities also benefit from bed levy and the monthly rental of land, which allows communities to make financial gains that can be directed towards social service investment and other developmental projects. With regard to the Mdluli project, it employs 68 full-time employees. Out of those 68 employees, 59 are from the local community, and $61 \%$ of those are women. So, the project goes beyond just providing employment and economic opportunities and tackling poverty and addresses gender equality, which is a key thematic area under SDG 5, on gender equality. Alarcón and Cole [43] argued that tourism could not be able to effectively tackle the SDGs without addressing the issue of gender equality.

The study also found that the other vehicle of employment used to provide employment is the public works programme sponsored by the National Department of Tourism and the parent ministry for SANParks, the Department of Environmental Affairs and Forestry Fisheries (DEAFF). Through the programme, 155 youths were employed by DEAFF in the entire park, with almost half of these being in the Southern part of the park. These part-time employees, who all come from the surrounding communities, gave testimony to the centrality of SANParks in creating employment and other economic opportunities for them and the communities they come from. From the 70 public work respondents, there was also a near 50:50 gender representation of men and women, as the park is an active promoter of gender equality at the workplace. 
The employees indicated that these SANParks projects greatly benefit them and their communities at large, even though the majority of them are in part-time positions. At least a third of the respondents $(30.88 \%)$ indicated that they get the critical skills they need to improve their livelihood, gain experience for future work and cultivate an entrepreneurial spirit. One of the major challenges faced by the first employment entrance in South Africa is work experience and the required soft skills. The public works programme provides an opportunity for the youths to get such critical experience, which leads to other job opportunities post contract termination. The public works programme also equips the youth with business skills, as it subcontracts youths in some of its operations. The contractor is trained on various aspects of business management, paving the way for the contractors to bid for tenders and other contracts elsewhere.

The youths involved in the public works programme embark on various projects, including furniture making, land rehabilitation, indigenous tree plantations, water management activities, alien invasive control, fire management and poaching control. These are areas with lucrative opportunities for youths to derive entrepreneurial opportunities to make a living easily. Given that furniture is always in demand for the local and regional market, the youths can use the acquired skills to start their own businesses in furniture manufacturing and create other jobs in the process. The eco-furniture project, which is part of the public works projects, uses recycled material. As such, the project also addresses the challenges associated with land pollution. Youths involved in the indigenous tree plantation project can also identify entrepreneurial opportunities by starting their own tree plantation, which can be accredited under the carbon sequestration projects and become a critical source of climate change action (SDG13) and green jobs initiative.

To ensure that the benefits of tourism reach the host communities, Kruger National Park has business incubation projects aimed at capacitating local businesses (small to medium enterprises) to produce the most in-demand products at the park, thereby creating a pool of local suppliers. Buying local has been at the core of responsible and sustainable tourism, as it assists local economies and in reducing the carbon footprint of the tourism business in general. The park therefore reserves a certain portion of its projects to entrepreneurs from host communities.

For example, in the financial year 2019/2020, after the Gomodwane land claim, KNP intended to train between 20 and 60 small to medium scheme enterprises in entrepreneurship and business development. They also sought to train trustee leadership in commercial business management and also impart critical business leadership skills. SANParks created business opportunities for 703 small to medium entrepreneurs worth about US \$ 13 million in the same financial year. In the previous financial year, SANParks had offered opportunities to 733 small and medium businesses with a monetary value of US \$ 15.4 million [44]. Out of the beneficiaries, $69 \%$ were youths, $2 \%$ were people with disabilities and $54 \%$ were women [45]. Such investment is crucial in ensuring economic participation for all. The focus on small businesses is also important, as it triggers rural development, which can also assist in lifting communities out of poverty. Small and medium enterprises have been reported to be critical drivers of rural economic development [46-48]. In other settings, small to medium scale enterprises have been credited with drastically reducing poverty $[49,50]$, which speaks directly to the aspirations of SDG1. The inclusion of rural communities also assists in addressing the challenge of huge inequalities in South Africa, particularly those between the rural populace and the urbanites by default, addressing SDG 10 on reducing inequalities.

Therefore, in that respect, it can be argued that Kruger national park is doing its part in addressing several targets outlined in SDG8 in various ways. Regardless of this contribution, there are challenges with regard to managing community expectations, as it is impractical for tourism entities like the national parks to employ every community member. As such, there is a need to broaden and diversify the scope of economic activities as part of the economic diversification to buffer the communities from the disaster of an over-reliance on one economic activity that is highly sensitive to natural and other disasters, as has been 
witnessed with climate change and COVID-19, which nearly wiped out tourism businesses across the world.

\subsection{Kruger National Park's Contribution to Health-, Food-and Education-Related SDGs}

It emerged from the study that the park, conscious of the challenges faced by the host communities, is involved in several projects that address real-life problems faced daily by the communities around Kruger National Park, such as health requirements, hunger and education. The instituted projects are aimed at improving rural livelihoods. One of the challenges faced by rural communities in South Africa is hunger and malnutrition. To improve the nutritional and food challenges faced by the surrounding communities, the park has a project that allows the surrounding communities to get into the park and sustainably harvest mopane worms, which are a local delicacy. In addition, KNP often culls animals and provides meat to neighbouring communities, particularly schools, and to school feeding projects. This is aimed at ensuring that students have a balanced diet, that promotes the healthy growth of children and addresses the problem of stunting, which is one of the biggest challenges faced by children in South Africa and in particular the Mpumalanga province, which is one of the provinces that hosts the Kruger National Park [51-53]. Child stunting is particularly problematic, as it affects the children's development, health and economic development [54,55].

According to Makhado, Potgieter, Timberlake and Gumbo [56], the mopane worms are quite nutritious, comprise $65 \%$ protein and provide an energy concentration of 543 $\mathrm{kcal} / 100 \mathrm{~g}$. Other scholars, such as Nantanga and Amakali [57], argued that mopane worms play a critical role in providing household food security, as they provide nutrients and micronutrients that are needed by the human body. Therefore, Kruger National Park's interventions are commendable, as they contribute to SDG 2, on Zero Hunger, and SDG 3, on Good Health and Wellbeing. KNP reported that besides the already reported interventions, they also allow for the sustainable harvesting of traditional medicines by traditional healers. The park also provides indigenous trees with medicinal and other socio-economic uses to communities that are planted at its Skukuza indigenous tree nursery.

Field observation showed that the nursery (Figure 1) has more than 200 tree species that are crucial to people's everyday health needs. Traditional medicines have been found to have a considerable role in the achievement of SDG 3 on Good Health [58-60]. Traditional medicines can offset some of the challenges faced by rural and poor communities in accessing health in South Africa, which is often beyond the reach of many. The trees provided have other crucial socio-economic purposes beyond just mediation. The nursery often makes donations of indigenous trees to education institutions so as to provide shade. The shade from such trees has a cooling effect on schools and provides shade during the hot summer days, as temperature in the region rises due to global warming. The trees, therefore, act as a form of climate change adaptation.

One of the footprints of Kruger National Park relates to education, as it provides many critical interventions. The park makes significant strides to support the initiatives by local institutions of education, from primary to secondary and tertiary educational institutions, locally and abroad. It emerged from the interviews that there are various interventions by KNP aimed at supporting teaching, learning and research. Kruger National Park has a full-fledged scientific service that conducts cutting-edge research and has assisted society in a wide range of issues about biodiversity in national parks and beyond. Figure 2 outlines the number of research projects registered and conducted within South African National Parks, and most of these are conducted at Kruger National Park. Given that some of these projects have a people component, such research works assist in improving local, regional and international livelihoods. Such research involves several university institutions, some of which have research stations in the park. 

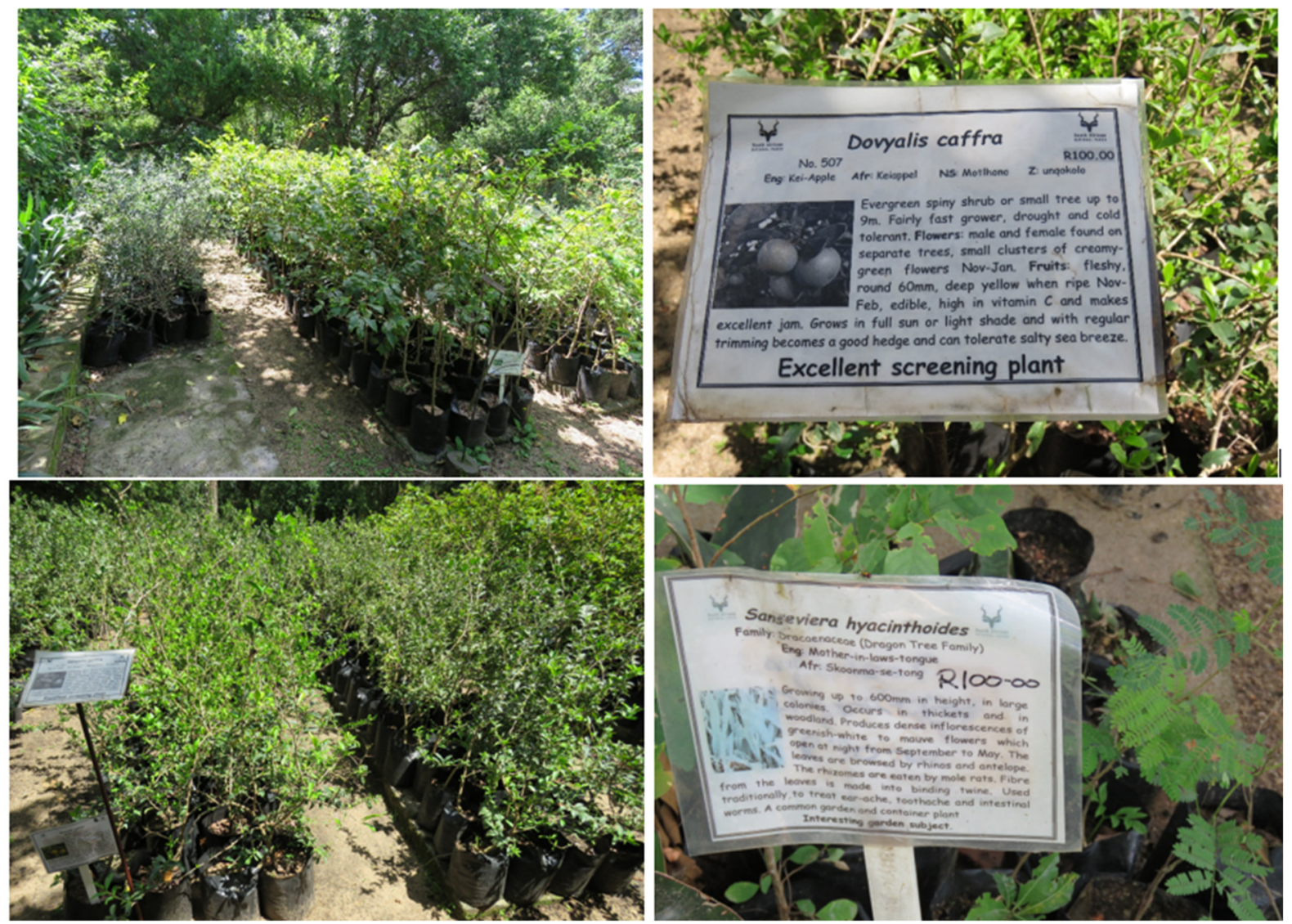

Figure 1. Image of some of the plants in the Skukuza nursery and placards showing medicinal and other daily usages.

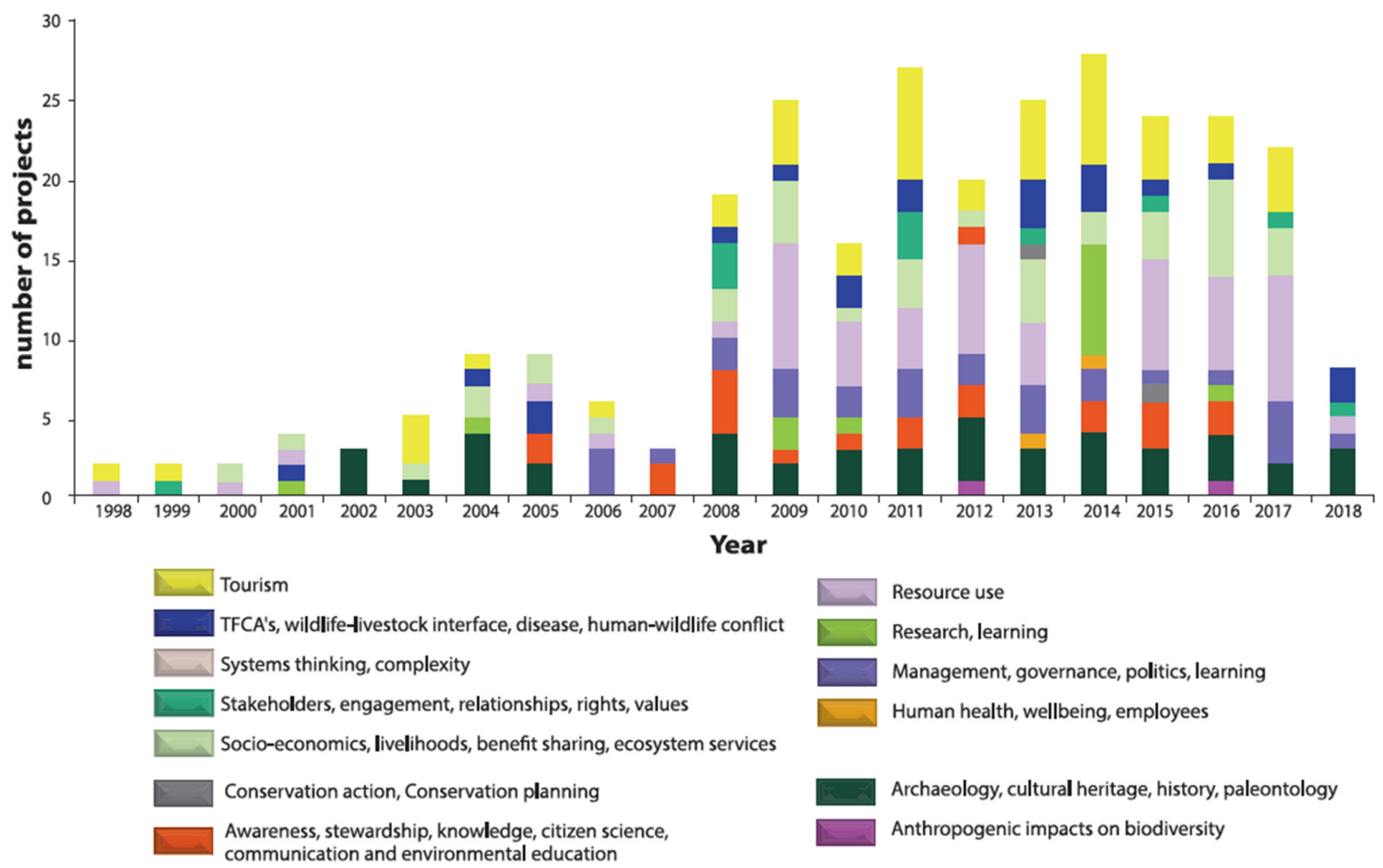

Figure 2. People component research projects registered by SANParks between 1998 and 2018. Source: SANParks p. 33 [61]. 
With regard to projects that directly assist host communities in bettering education, the park, among other things, contributes to the learning of Mathematics and Science in local high schools through the construction of science laboratories. Over the years, through the legacy project, Kruger National Park assisted or is in the process of constructing science laboratories worth millions of rand at Bunny Khosa and Jacob Mdluli Secondary school. Success in Mathematics and Science remains a challenge in South Africa due to various reasons that affect the education sector $[62,63]$. Educators interviewed indicated that one of the critical components in the motivation and learning of science to ensure that students pass well is the availability of well-equipped science laboratories. One principal noted that " ... we wish for the laboratory that is being constructed by SANParks to be completed as a matter of urgency so that we can improve on the pass rate which currently is hampered by lack of equipped laboratory." This assertion was confirmed by a scrutiny of the results that showed that out of all the subjects offered at the school, only Mathematics and Science had a grade average of below $50 \%$, which ultimately affects the future progression of the affected students.

Kruger National Park also invested in the construction of ablution facilities at phase 2 Makushu Primary School. The project, that cost close to half a million rand, is critical in the proper management and running of primary schools lacking basic amenities. Addressing the need for basic amenities for community members is crucial, as it addresses the water and sanitation challenges faced by rural communities battling service delivery challenges. Other tourism establishments with concessions in the KNP were also investing in sanitation programmes [64].

In addition to Kruger National Park's science interventions, it also had initiatives of cultivating a tourism culture amongst students from host communities. The park provides free entry for educational institutions surrounding the park through initiatives such as the Walk and Learn and conducts teacher's seminars to assist in enhancing teaching and learning. SANParks works in partnership with Total Fuel Company and other businesses in funding a project that exposes students to conservation and biodiversity issues. The programme takes students and exposes them to the world of tourism and hospitality. Such exposures, which also provide career guidance, are critical in motivating students and ensuring quality education for the largely impoverished communities.

\subsection{Kruger National Parks and Cultural and Environmental Related SDGs}

SDG 11 calls for the promotion of sustainable communities. SDG 11.4 calls for the protection of cultural and natural heritage sites. Cultural heritage is a critical driver of socioeconomic development and a tourism drawcard [65-67]. Given its historical background, KNP has over 255 heritage sites that date to the Early Stone age period, which was about 1 million years ago. Such archaeological sites are important, as they add value to wildlife tourism. These sites are also important cultural sites for the host communities, which have a strong historical linkage with the national park. As such, they are crucial to the spiritual life and history of the area, the country and the region. Some of the most prominent sites that have been opened to the public include the Albasini Ruins, Masorini, a late Stone Age site and Thulamela, a late Iron Age site that has links to Great Zimbabwe and Mapungubwe, which are both World Heritage Sites. KNP also has a museum where artefacts and other important archaeological objects are preserved. Artefacts and other historical objects are at risk from theft, graffiti and climate change. Their preservation, therefore, is a significant development that contributes to their sustainability.

In the southern region of the park in 2020, Kruger National Park unveiled the grave of Chief Nyongane, who has a historical claim to parts of the land now occupied by the park. Such historical sites give life and meaning to the park from an African perspective and are important spiritual sites. KNP often assists host communities to interact with such sites as part of cultural preservation. Besides being cultural tourism sites, local people access such sites to conduct important cultural rituals. 
Kruger National Park has robust environmental programmes for host communities to address various environmental challenges. The KNP leverages its rich linkages to facilitate funding for some of these community projects. Given its vintage and strategic human capital resources, the park is assisting with the provision of clean water through a partnership with Bushbuckridge Local Municipality to provide clean water for the community that lies at its border. Given water challenges faced by the communities of Thulani, Belfast and Cork, KNP partnered with the municipality to ensure that the community has access to clean and safe drinking water. The project, which was completed in 2020, was funded to the tune of R8.1 million rand. The project responds to the calls for universal access to affordable drinking water for all by 2030 SDG6, target 6.1. One of the major disruptors to tourism in Kruger National Park is a community service delivery protest addressing one of the critical challenges faced by host communities; SANParks and the host community benefit from this noble collaboration.

Kruger National Park was also involved in projects that foster health and a clean environment by investing in environmental education and waste management programmes to schools and neighbouring communities. Through the five environmental interpretation centres, KNP has several interpretation centres. It has both curriculum and non-funded curriculum projects aimed at ensuring environmental sustainability. The non-curriculum projects are aimed at promoting land rehabilitation, clean-up campaigns and community greening projects. Figure 3 shows the number of participants of various KNP environmental programmes. Through the environmental education programmes, SANParks can bring to the fore issues and challenges facing host communities using part of the money from the Tourism Levy, which is charged to each tourist as they enter SANParks across the country. These projects' critical issues include climate change, pollution, human-wildlife conflict, poaching and other critical environmental problems.

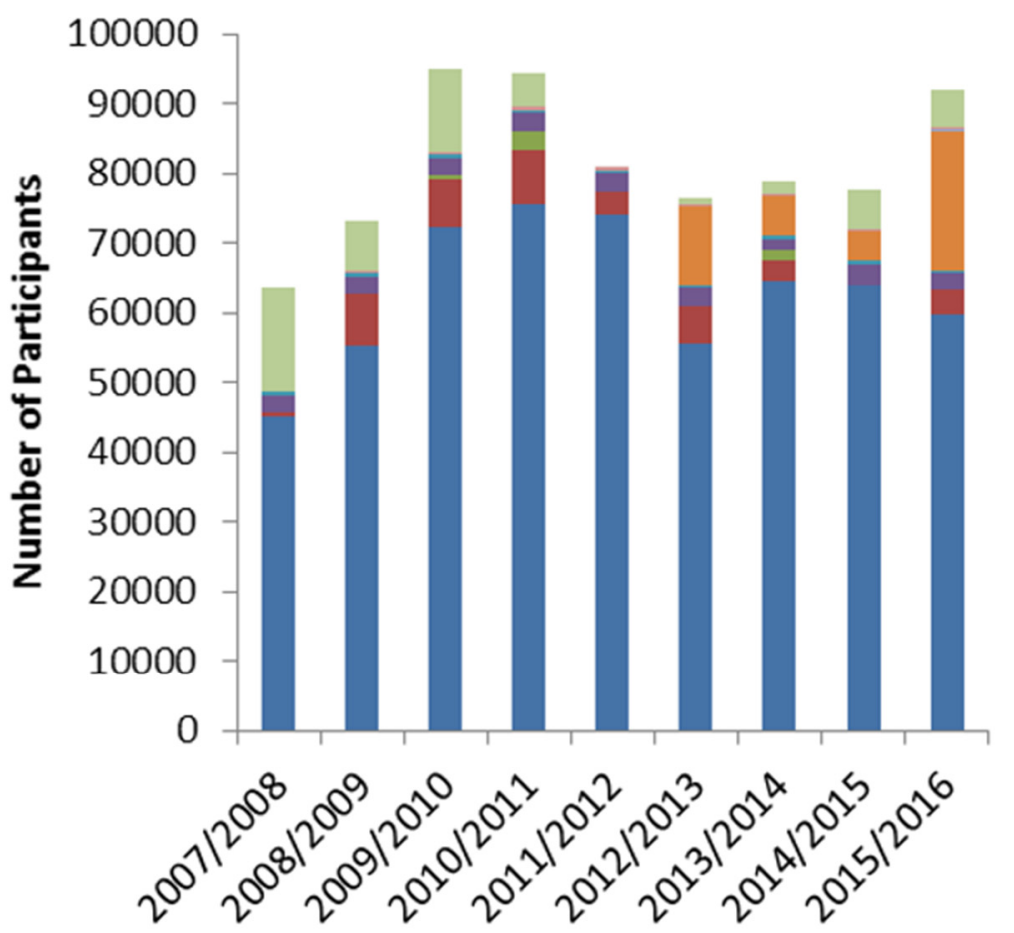

Kruger to Kasie

Walk \& Learn on the

Wildside

School Journey Programme

Outreach

Kids in Parks

Kids in Kruger

Special Group day

Programmes

- Community Group day

programmes

School day Programmes

\section{Financial Year}

Figure 3. A break down of the population reached through formal KNP environmental education programmes between 2007 and 2016.

One of its flagship projects was noted to be a recycling project that attracted funding from Coca-Cola and now runs a well-functioning recycling project that also generates money for the beneficiaries. Waste Management is a very big challenge in South Africa, 
that affects both terrestrial and aquatic environments. Besides being an eyesore to tourists in Kruger National Park, some waste can be dangerous to people and animals, particularly aquatic and marine life. Waste management initiatives in the host communities help them navigate and foster the ethos of SDG 12 on responsible consumption and production. It emerged from key informant interviews that formed part of the environmental education programme, and it encourages people to grow indigenous trees. One such indigenous tree that has been distributed to communities is the Kei-Apple Tree (Dovyaliscaffra). The tree has numerous usages. Its fruits can be used to make fruit jam. One of the biggest benefits of promoting the planting of indigenous trees is their biodiversity role and the fact that they also act as carbon sinks in the battle against climate change, thereby talking directly to SDG 13, on climate change action, and SDG 15, on life on land.

According to Malherbe, Smit, Wessels and Beukes [68], Kruger National Park and the surrounding areas are prone to climate-change-induced droughts, which have adversely affected the flora and fauna, pushing some species to the verge of extinction. Through its animal loan programme, SANParks embarked through KNP on a project that might assist in buffering the impact of climate change on biodiversity. The animal loan scheme programme has socio-economic and environmental benefits. KNP, through the programme, promotes the entrance of previously disadvantaged communities to enter game farming projects. This is a crucial project which ensures that there are species banks along the park boundaries. One other critical push is the removal of fences with neighbouring game farms and other concession areas, which allows for a diversified gene pool that militates against inbreeding and other challenges associated with small game farm units addressing SDG 15 and 13 , all at once.

\subsection{Kruger National Parks and Community Justice and Peace Efforts}

Like any other protected area in the world, Kruger National Park faces several challenges related to human-wildlife conflicts. This situation is compounded by the fact that Kruger National Park was built largely from sweat, tears and suffering of the disposed local people, who were robbed of their land, and often violently so. For a long time, KNP was a sanctuary of the rich elite surrounded by a sea of poverty, which often led to escalating tensions between the two communities. Some of the injustices emanating from the establishment are well document by Massé [69]. KNP has been making some effort to amend some of these past injustices by addressing some of the neighbouring communities' grievances. One such initiative is to offer some form of compensation if livestock attacks livestock from the neighbouring communities, although there is no legal obligation to do so. The community's inclusion in the drawing up of the park's management plan and the consultative approach linked in through community forums help foster peace and some form of justice for the aggrieved communities. In several ways, the KNP is accountable and responsive to the communities it works in, which advances the ethos set out in SDG16, on peace and justice. There are deliberate efforts to ensure that the local communities have a stake in some of the park's tourism spin-offs. There is some level of transparency in how SANParks operates and works with host communities, as assumed in SDG16.

Regardless of these achievements, there are challenges with regard to the implementation of community projects beyond the scope of what KNP can do. Although on paper these are democratically constituted, these forums are vulnerable to abuse and manipulation by those with power and authority, which can trigger community conflict, as some stand to benefit more than others.

\section{Discussion of Key Results}

The study has shown that South African National Parks, through Kruger National Park, has been active in creating partnerships with the host community to advance host communities' developmental agenda. It emerged from the study that the park is making significant strides to address issues that other tourism players in the tourism industry are striving to tackle. At the heart of protected areas is the aspect of ensuring environmental 
sustainability, which forms the core of Kruger National Park's environmental education drive. A study by Dube and Nhamo [8] revealed that Grootbos Private Game Reserve, in South Africa's Western Cape, was also making similar initiatives, as nature forms the core of any tourism enterprise.

Tourism has always been regarded as an industry that is at the forefront of tackling socio-economic development challenges such as addressing poverty, education issues and unemployment. It is equally clear from the case study that Kruger National Park does put a lot of focus and emphasis on ensuring that it contributes to the socio-economic development of host communities. This is quite similar to other enterprises in the tourism industry that have focused on the same aspects [70-72]. This highlights the critical role that tourism plays in the global economy. Yet perhaps of striking significance in this study was the role of the national park in tackling climate change, an issue that has attracted global concern and attention within the tourism industry. The sector has been adopting a variety of measures to address the climate change challenges within the SDG framework, such as the adoption of the green building concept and embracing other greenways [73,74].

However, the Park emerges as one of the enterprises in the tourism industry that addresses SDG16, on peace and justice, to a certain degree. The shift in adopting a more transformative approach in tourism management involving the indigenous population groups is critical, as it acknowledges the prejudices suffered by the indigenous people who occupied the space now occupied by the park. Some initiatives aimed at addressing the grievances of the host community, who are often victims of the park establishment, are commendable, as they provide models for other parks across the world.

\section{Conclusions and Recommendations}

The study sought to examine how KNP, through responsible tourism, assists communities in meeting some of their SDG developmental targets. The study found that SANParks, through Kruger National Park, is assisting in several goals with programmes speaking to at least 15 of the 17 SDGs. Given the size of KNP, it creates several job opportunities, either directly or indirectly, which have helped tackle extreme poverty in rural areas. The park also creates several business opportunities that have helped grow the local economy through several deliberate interventions, such as the business incubation programme aimed at growing small to medium enterprises triggering rural development through responsible tourism. As a conservation-based organisation, Kruger National Park has sought to promote the conservation of natural and cultural heritage sites for the benefit of the local, regional and international community. The environment's educational awareness has helped in creating entrepreneurial opportunities for host communities, that can tap into several projects. KNP is one of the tourism enterprises taking active steps to tackle peace and justice within the park by incorporating host communities into its programmes and activities. The findings of this study are critical and can be used as a model for other parks. In addition, it highlights successes and challenges in SDG localization in the global South.

Regardless of SANParks' contribution to the lives of host communities, numerous challenges lie ahead of the community and Kruger National Park. One of the challenges faced by KNP is managing the expectations of host communities. As an enterprise, KNP can only do so much for host communities and make this understandable to them, as they will always want more. The well-intentioned community projects are unlikely to benefit every community member; as such, there is a need for a model that will ensure that the park's benefits have reached the poor of the poorest. There is, therefore, a need to continuously invest time and research into finding that suitable model. There is also a need for studies on the cost and opportunities and the efficacy of traditional leadership in community share schemes from protected areas, as it is not clear whether communities end up benefiting from such schemes. The COVID-19 pandemic is likely to hurt several community projects, as tourism supply and demand have been severely affected. There is a need to provide a sustainable intervention to offset the adverse united consequences of COVID-19 in the tourism sector. Given the disruptions caused by COVID-19, it might be critical to evaluate 
how the pandemic has affected SANParks' efforts to adhere to sustainable and responsible tourism dictates.

\section{Study Limitations}

Given the limitations placed by the COVID-19 pandemic, it was not possible to interact with the generality of the host community, which could have altered the findings and views of host communities. Therefore, the study findings have to be understood in the context of the research study participants that could be reached.

Author Contributions: Conceptualization, M.A.M.; methodology, M.A.M.; software, K.D.; validation, K.T.; formal analysis, M.A.M.; investigation, M.A.M.; resources, K.D. data curation, M.A.M.; writingoriginal draft preparation, M.A.M.; writing-review and editing, K.D.; visualization, M.A.M.; supervision, K.D. and K.T.; project administration, K.D.; funding acquisition, M.A.M. All authors have read and agreed to the published version of the manuscript.

Funding: This research was funded by the National Research Fund (NRF) of South Africa Grant No: 122886.

Institutional Review Board Statement: The study was conducted according to the guidelines of the Declaration of Helsinki, and ap-proved by the Vaal University of Technology Faculty Research Ethics Committee Ref Number FREC/HS/02/10/2020/6.1.3 and approved on 23 October 2020.

Informed Consent Statement: Informed consent was obtained from all subjects involved in the study.

Data Availability Statement: Data available upon request.

Conflicts of Interest: The authors declare no conflict of interest.

\section{References}

1. Stoldt, M.; Göttert, T.; Mann, C.; Zeller, U. Transfrontier conservation areas and human-wildlife conflict: The case of the Namibian component of the Kavango-Zambezi (KAZA) TFCA. Sci. Rep. 2020, 10, 1-16. [CrossRef]

2. Siljander, M.; Kuronen, T.; Johansson, T.P.; Munyao, M.N.; Pellikka, P.K.E. Primates on the farm-spatial patterns of human-wildlife conflict in forest-agricultural landscape mosaic in Taita Hills, Kenya. Appl. Geogr. 2020, 117, 102185. [CrossRef]

3. Long, H.; Mojo, D.; Fu, C.; Wang, G.; Kanga, E.; Oduor, A.M.; Zhang, L. Patterns of human-wildlife conflict and management implications in Kenya: A national perspective. Hum. Dimens. Wildl. 2020, 25, 121-135.

4. Karanth, K.K.; Vanamamalai, A. Wild seve: A novel conservation intervention to monitor and address human-wildlife conflict. Front. Ecol. Evol. 2020, 8, 198. [CrossRef]

5. Madden, F. Creating Coexistence between humans and wildlife: Global perspectives on local efforts to address human-wildlife conflict. Hum. Dimens. Wildl. 2004, 9, 247-257. [CrossRef]

6. Hall, C.M. Constructing sustainable tourism development: The 2030 agenda and the managerial ecology of sustainable tourism. J. Sustain. Tour. 2019, 27, 1044-1060. [CrossRef]

7. Adie, B.A.; Amore, A.; Hall, C.M. Just because it seems impossible, doesn't mean we shouldn't at least try: The need for longitudinal perspectives on tourism partnerships and the SDGs. J. Sustain. Tour. 2020, 1-16. [CrossRef]

8. Dube, K.; Nhamo, G. Sustainable development goals localisation in the tourism sector: Lessons from Grootbos Private Nature Reserve, South Africa. GeoJournal 2020, 1-18. [CrossRef]

9. Hallegatte, S.; Rozenberg, J. Climate change through a poverty lens. Nat. Clim. Chang. 2017, 7, 250-256. [CrossRef]

10. Manzoor, F.; Wei, L.; Asif, M.; Haq, M.Z.U.; Rehman, H.U. The contribution of sustainable tourism to economic growth and employment in Pakistan. Int. J. Environ. Res. Public Health 2019, 16, 3785. [CrossRef]

11. Aall, C. Sustainable tourism in practice: Promoting or perverting the quest for a sustainable development? Sustainability 2014, 6, 2562-2583. [CrossRef]

12. Liburd, J.; Duedahl, E.; Heape, C. Co-designing tourism for sustainable development. J. Sustain. Tour. 2020, 1-20. [CrossRef]

13. Chidakel, A.; Eb, C.; Child, B. The comparative financial and economic performance of protected areas in the Greater Kruger National Park, South Africa: Functional diversity and resilience in the socio-economics of a landscape-scale reserve network. J. Sustain. Tour. 2020, 28, 1100-1119. [CrossRef]

14. Siakwah, P.; Musavengane, R.; Leonard, L. Tourism governance and attainment of the sustainable development goals in Africa. Tour. Plan. Dev. 2020, 17, 355-383. [CrossRef]

15. Sharpley, R. Tourism, sustainable development and the theoretical divide: 20 years on. J. Sustain. Tour. 2020, 28, 1932-1946. [CrossRef]

16. Stone, M.T.; Nyaupane, G.P. Protected areas, tourism and community livelihoods linkages: A comprehensive analysis approach. J. Sustain. Tour. 2016, 24, 673-693. [CrossRef] 
17. Stone, L.S.; Stone, T.M. Community-based tourism enterprises: Challenges and prospects for community participation; Khama Rhino Sanctuary Trust, Botswana. J. Sustain. Tour. 2011, 19, 97-114. [CrossRef]

18. Doubleday, K.F. Tigers and "good Indian wives": Feminist political ecology exposing the gender-based violence of human-wildlife conflict in Rajasthan, India. Ann. Am. Assoc. Geogr. 2020, 110, 1521-1539. [CrossRef]

19. Braczkowski, A.; Fattebert, J.; Schenk, R.; O’Bryan, C.; Biggs, D.; Maron, M. Evidence for increasing human-wildlife conflict despite a financial compensation scheme on the edge of a Ugandan National Park. Conserv. Sci. Pract. 2020, 2, 12. [CrossRef]

20. Fang, L.; Hong, Y.; Zhou, Z.; Chen, W. The frequency and severity of crop damage by wildlife in rural Beijing, China. For. Policy Econ. 2021, 124, 102379. [CrossRef]

21. Swemmer, L.; Mmethi, H.; Twine, W. Tracing the cost/benefit pathway of protected areas: A case study of the Kruger National Park, South Africa. Ecosyst. Serv. 2017, 28, 162-172. [CrossRef]

22. Lekaota, L.; Khashane, R. Local communities' perceptions on the role of tourism in. Afr. J. Hosp. Tour. Leis. 2019, 8, 1-14.

23. Leonard, L.; Thomas, P. The Potential for Geotourism at the Kruger National Park for Social Sustainability. Ph.D. Thesis, University of Johannesburg, Johannesburg, South Africa, 2020. Available online: https://ujcontent.uj.ac.za/vital/access/ services/Download/uj:40477/SOURCE1 (accessed on 3 February 2021).

24. Lenao, M.; Moswete, N.; Stone, M.T. Natural resources, tourism and community livelihoods relationships: Contemplating the future. In Natural Resources, Tourism and Community Livelihoods in Southern Africa: Challenges of Sustainable Development; Routledge: New York, NY, USA, 2019; p. 223.

25. Pope, J.; Wessels, J.-A.; Douglas, A.; Hughes, M.; Morrison-Saunders, A. The potential contribution of environmental impact assessment (EIA) to responsible tourism: The case of the Kruger National Park. Tour. Manag. Perspect. 2019, 32, 100557. [CrossRef]

26. Strickland-Munro, J.K.; Moore, S.A.; Freitag-Ronaldson, S. The impacts of tourism on two communities adjacent to the Kruger National Park, South Africa. Dev. S. Afr. 2010, 27, 663-678. [CrossRef]

27. UNWTO. 2017 Is the International Year of Sustainable Tourism for Development; World Tourism Organization: Madrid, Spain, 2017.

28. Rasoolimanesh, S.M.; Ramakrishna, S.; Hall, C.M.; Esfandiar, K.; Seyfi, S. A systematic scoping review of sustainable tourism indicators in relation to the sustainable development goals. J. Sustain. Tour. 2020, 1-21. [CrossRef]

29. Kimbu, A.N.; Tichaawa, T.M. Tourism and sustainable development goals in the African context. Int. J. Econ. Financ. Stud. 2020, 12, 88-102. [CrossRef]

30. Musavengane, R. Small hotels and responsible tourism practice: Hoteliers' perspectives. J. Clean. Prod. 2019, 220, 786-799. [CrossRef]

31. Morrison-Saunders, A.; Hughes, M.; Pope, J.; Douglas, A.; Wessels, J.-A. Understanding visitor expectations for responsible tourism in an iconic national park: Differences between local and international visitors. J. Ecotour. 2019, 18, 284-294. [CrossRef]

32. Lee, H.Y.; Bonn, M.A.; Reid, E.L.; Kim, W.G. Differences in tourist ethical judgment and responsible tourism intention: An ethical scenario approach. Tour. Manag. 2017, 60, 298-307. [CrossRef]

33. Mutandwa, E.; Gadzirayi, C.T. Impact of community-based approaches to wildlife management: Case study of the CAMPFIRE programme in Zimbabwe. Int. J. Sustain. Dev. World Ecol. 2007, 14, 336-344. [CrossRef]

34. Mathew, P.V.; Sreejesh, S. Impact of responsible tourism on destination sustainability and quality of life of community in tourism destinations. J. Hosp. Tour. Manag. 2017, 31, 83-89. [CrossRef]

35. Movono, A.; Hughes, E. Tourism partnerships: Localizing the SDG agenda in Fiji. J. Sustain. Tour. 2020, 1-15. [CrossRef]

36. Stone, L.S.; Mogomotsi, P.K.; Stone, M.T.; Mogomotsi, G.E.J.; Malesu, R.; Somolekae, M. Sustainable tourism and the SDG's in Botswana: Prospects, opportunities and challenges towards 2030. In Sustainability in Developing Countries; Springer: Cham, Switzerland, 2020; pp. 153-181.

37. Dube, K.; Nhamo, G. Evidence and impact of climate change on South African national parks. Potential implications for tourism in the Kruger National Park. Environ. Dev. 2020, 33, 100485. [CrossRef]

38. Jersild, A.T.; Meigs, M.F. Chapter V: Direct observation as a research method. Rev. Educ. Res. 1939, 9, 472-482. [CrossRef]

39. Mulhall, A. In the field: Notes on observation in qualitative research. J. Adv. Nurs. 2003, 41, 306-313. [CrossRef] [PubMed]

40. Heale, R.; Forbes, D. Understanding triangulation in research. Évid. Based Nurs. 2013, 16, 98. [CrossRef]

41. Harper, D.; Andrew, R.T. Qualitative Research Methodsi Mental Health and Psychotherapy: A Guide for Students and Practitioners; John Wiley \& Sons: Hoboken, NJ, USA, 2011.

42. United Nations (UN). Transforming Our World: The 2030 Agenda for Sustainable Development. 2015. Available online: https:/ / sustainabledevelopment.un.org/content/documents /21252030\%20Agenda\%20for\%20Sustainable \%20Development $\%$ 20web.pdf (accessed on 11 July 2020).

43. Alarcón, D.M.; Cole, S. No sustainability for tourism without gender equality. J. Sustain. Tour. 2019, 27, 903-919. [CrossRef]

44. South African National Parks. Annual Report 2018/2019; South African National Parks: Pretoria, South Africa, 2019.

45. South African National Parks. Annual Report 2017/2018; South African National Parks: Pretoria, South Africa, 2018.

46. Baker, H.K.; Kumar, S.; Pandey, N. Thirty years of Small Business Economics: A bibliometric overview. Small Bus. Econ. 2021, 56, 487-517. [CrossRef]

47. Amoah, S.K.; Amoah, A.K. The role of small and medium enterprises (SMEs) to employment in Ghana. Int. J. Bus. Econ. Res. 2018, 7, 151-157. [CrossRef]

48. AlBar, A.M.; Hoque, M.R. Factors affecting the adoption of information and communication technology in small and medium enterprises: A perspective from rural Saudi Arabia. Inf. Technol. Dev. 2019, 25, 715-738. [CrossRef] 
49. Maksimov, V.; Wang, S.L.; Luo, Y. Reducing poverty in the least developed countries: The role of small and medium enterprises. J. World Bus. 2017, 52, 244-257. [CrossRef]

50. Fatoki, O. The impact of entrepreneurial resilience on the success of small and medium enterprises in South Africa. Sustainability 2018, 10, 2527. [CrossRef]

51. Madiba, S.; Chelule, P.K.; Mokgatle, M.M. Attending informal preschools and daycare centers is a risk factor for underweight, stunting and wasting in children under the age of five years in underprivileged communities in South Africa. Int. J. Environ. Res. Public Health 2019, 16, 2589. [CrossRef]

52. Du Plessis, L.; Daniels, L.; Koornhof, H.; Samuels, S.; Möller, I.; Röhrs, S. Overview of field-testing of the revised, draft South African Paediatric Food-Based Dietary Guidelines amongst mothers/caregivers of children aged 0-5 years in the Western Cape and Mpumalanga, South Africa. S. Afr. J. Clin. Nutr. 2021, 1-9. [CrossRef]

53. Möller, I.; Du Plessis, L.; Daniels, L. Field-testing of the revised, draft South African paediatric food-based dietary guidelines among Siswati-speaking mothers/caregivers of children aged 0-36 months in Kabokweni, Mpumalanga Province, South Africa. S. Afr. J. Clin. Nutr. 2021, 1-6. [CrossRef]

54. McGovern, M.E.; Krishna, A.; Aguayo, V.M.; Subramanian, S.V. A review of the evidence linking child stunting to economic outcomes. Int. J. Epidemiol. 2017, 46, 1171-1191. [CrossRef]

55. Perkins, J.M.; Kim, R.; Krishna, A.; McGovern, M.; Aguayo, V.M.; Subramanian, S. Understanding the association between stunting and child development in low- and middle-income countries: Next steps for research and intervention. Soc. Sci. Med. 2017, 193, 101-109. [CrossRef]

56. Makhado, R.; Potgieter, M.; Timberlake, J.; Gumbo, D. A review of the significance of mopane products to rural people's livelihoods in southern Africa. Trans. R. Soc. S. Afr. 2014, 69, 117-122. [CrossRef]

57. Nantanga, K.K.; Amakali, T. Diversification of mopane caterpillars (Gonimbrasiabelina) edible forms for improved live-lihoods and food security. J. Arid Environ. 2020, 177, 104148. [CrossRef]

58. World Health Organization. WHO Global Report on Traditional and Complementary Medicine 2019; World Health Organization: Geneva, Switzerland, 2019.

59. Kasilo, O.M.J.; Wambebe, C.; Nikiema, J.B.; Nabyonga-Orem, J. Towards universal health coverage: Advancing the development and use of traditional medicines in Africa. BMJ Glob. Health 2019, 4, e001517. [CrossRef]

60. Ojagbemi, A.; Gureje, O. The potential role of traditional medicine in the management of schizophrenia. Curr. Psychiatry Rep. 2020, 22, 1-7. [CrossRef] [PubMed]

61. South African National Parks. 2018/2019 Research Report; South African National Parks: Pretoria, South Africa, 2019.

62. Adler, J.; Pillay, V. Mathematics Education in South Africa. Research for Educational Change: Transforming Researchers' Insights into Improvement in Mathematics Teaching and Learning; Routledge: Oxfordshire, UK, 2017; pp. 9-24.

63. Mbhiza, H.W. A critical exploring of grade 10 rural learners' experiences and attitudes towards learning mathematics in Acornhoek classrooms, Mpumalanga Province. Ph.D. Thesis, University of the Witwatersrand, Johannesburg, South Africa, 2017.

64. Dube, K.; Nhamo, G.; Mearns, K. \&Beyond's response to the twin challenges of pollution and climate change in the context of SDGs. In Scaling up SDGs Implementation; Sustainable Development Goals Series; Springer: Cham, Switzerland, 2020; pp. 87-98.

65. Bonet, L. Heritage tourism. In Handbook on the Economics of Cultural Heritage; Edward Elgar Publishing: Cheltenham, UK, 2013; pp. 386-401.

66. Dans, E.P.; González, P.A. Sustainable tourism and social value at World Heritage Sites: Towards a conservation plan for Altamira, Spain. Ann. Tour. Res. 2019, 74, 68-80. [CrossRef]

67. García-Hernández, M.; De La Calle-Vaquero, M.; Yubero, C. Cultural heritage and urban tourism: Historic city centres under pressure. Sustainability 2017, 9, 1346. [CrossRef]

68. Malherbe, J.; Smit, I.P.; Wessels, K.J.; Beukes, P.J. Recent droughts in the Kruger National Park as reflected in the extreme climate index. Afr. J. Range Forage Sci. 2020, 37, 1-17. [CrossRef]

69. Massé, F. The political ecology of human-wildlife conflict: Producing wilderness, insecurity, and displacement in the Limpopo National Park. Conserv. Soc. 2016, 14, 100. [CrossRef]

70. Musavengane, R.; Simatele, D.M. Community-based natural resource management: The role of social capital in collaborative environmental management of tribal resources in KwaZulu-Natal, South Africa. Dev. S. Afr. 2016, 33, 806-821. [CrossRef]

71. Haibo, C.; Ayamba, E.C.; Udimal, T.B.; Agyemang, A.O.; Ruth, A. Tourism and sustainable development in China: A review. Environ. Sci. Pollut. Res. 2020, 27, 39077-39093. [CrossRef]

72. Trupp, A.; Dolezal, C. Tourism and the sustainable development goals in Southeast Asia. Austrian J. South-East Asian Stud. 2020, 13, 1-16.

73. Fennell, D.A.; Bowyer, E. Tourism and sustainable transformation: A discussion and application to tourism food consumption. Tour. Recreat. Res. 2020, 45, 119-131. [CrossRef]

74. Dube, K.; Mearns, K. Tourism and recreational potential of green building a case study of Hotel Verde cape town. In The Green Building Evolution; Nhamo, G., Mjimba, V., Eds.; Human Sciences Research Council: Pretoria, South Africa, 2019 ; pp. $200-219$. 